\title{
Effect of dermcidin, an antimicrobial peptide, on body fat mobilization in normal mice
}

\author{
Kyung-Ah Kim ${ }^{1, *}$, Sun-O Ka ${ }^{1, *}$, Woo Sung Moon ${ }^{2}$, Ho-Keun $\mathrm{Yi}^{3}$, Young-Hoon Lee ${ }^{4}$, \\ Kang-Beom Kwon ${ }^{\mathbf{5}}$, Jin-Woo Park ${ }^{1}$ and Byung-Hyun Park ${ }^{1}$ \\ Departments of ${ }^{1}$ Biochemistry and ${ }^{2}$ Pathology, Medical School and Institute for Medical Sciences, ${ }^{3}$ Biochemistry and \\ ${ }^{4}$ Oral Anatomy, Dental School and Institute of Oral Biosciences, Chonbuk National University, Jeonju, Jeonbuk 561-756, South Korea \\ ${ }^{5}$ Department of Physiology, School of Oriental Medicine, Wonkwang University, Iksan, Jeonbuk 570-749, South Korea \\ (Correspondence should be addressed to B-H Park; Email: bhpark@chonbuk.ac.kr) \\ *(K-A Kim and S-O Ka contributed equally to this work)
}

\begin{abstract}
Dermcidin (DCD), an antimicrobial peptide that is secreted by sweat glands, is reportedly a human homolog of mouse proteolysis-inducing factor. This study was conducted to investigate the effect of DCD on body fat mobilization. The expression level of DCD in the livers of Ad-DCD-injected mice was higher than in those of Ad- $\beta$-galactosidase (Ad- $\beta$ gal)-injected mice 7 days after injection. In addition, injection with the Ad-DCD virus led to decreased body weight and epididymal fat mass when compared with controls. The plasma triglyceride level was decreased, whereas the free fatty acid and glycerol levels were increased in the Ad-DCDinjected group. Epididymal adipose tissues obtained from Ad-DCD-injected mice consisted of smaller adipocytes than
\end{abstract}

tissues obtained from Ad- $\beta$-gal-injected mice. The gene expression profiles revealed an upregulation of hormonesensitive lipase and adipose fatty acid-binding protein, both of which are involved in adipocyte lipolysis, in Ad-DCDinjected mice, and this lipolytic effect of DCD paralleled the increase of circulating tumor necrosis factor- $\alpha$ (TNF- $\alpha$ ) level that was observed. The perilipin levels in adipose tissue were decreased in Ad-DCD-injected mice when compared with those of the control mice. Taken together, these results suggest that DCD-mediated body fat reduction might occur as a result of TNF- $\alpha$-induced downregulation of perilipin in adipose tissue.

Journal of Endocrinology (2008) 198, 111-118

\section{Introduction}

Dermcidin (DCD) was originally identified as a gene that was responsible for the production of DCD-1, a proteolytically processed product of DCD secreted by eccrine sweat glands (Schittek et al. 2001). The full-length DCD gene consists of 110 amino acid (aa) residues, with an N-terminal 19 aa signal peptide that is characteristic of the secreted proteins (Fig. 1A). In eccrine sweat, differently processed DCD-derived C-terminal peptides comprising 48 aa residues (DCD-1L), 47 aa residues (DCD-1), and shorter fragments were detected (Flad et al. 2002), and additional studies confirmed the antimicrobial activity of DCD-1L and DCD-1 against a variety of pathogenic micro-organisms (Schittek et al. 2001, Vuong et al. 2004, Lai et al. 2005). Human sweat contains $1-10 \mu \mathrm{g} / \mathrm{ml}$ DCD -1 , which is a concentration that is toxic to most micro-organisms that have been tested (Flad et al. 2002). Using serial analysis of gene expression, Porter et al. (2003) identified DCD as a candidate oncogene in breast cancer and suggested that DCD plays a role in tumorigenesis by enhancing cell growth and survival in a subset of breast carcinomas. In addition, others have recently reported that DCD might also function as an oncogene in hepatic cells (Lowrie et al. 2006) and prostate cancer cells (Stewart et al. 2007).

It has been reported that the $\mathrm{N}$-terminal 30 amino acid peptide of DCD, which is known as either survivalpromoting peptide, diffusible survival evasion peptide (DSEP), or Y-P 30 (Cunningham et al. 1998, 2002), promotes neural cell survival under oxidative conditions. Y-P 30 is a product of the same region of DCD as the core peptide of proteolysis-inducing factor (PIF) that has been identified as a cachectic factor that was purified from cachexia-inducing murine tumors and urine of patients with pancreatic cancer that experienced weight loss (Todorov et al. 1996, Wigmore et al. 2000). In addition, PIF elicits intense skeletal muscle catabolism in muscle cells and in animals (Lorite et al. 1997, 1998, Smith et al. 1999). DCD has been reported to be a human homolog of mouse PIF, based on a $90 \%$ amino acid similarity with the 20 amino acid sequence that has been described for mouse PIF and the N-terminal 20 amino acid sequence of DCD (Monitto et al. 2004). Although DCD has 
A

MRFMTLLFLTALAGALVCAYDPEAASAPGSGNPCHEASAAQKENAGEDPGL ARQAPKPRKQRSSLLEKGLDGAKKAVGGLGKLGKDAVEDLESVGKGAVH DVKDVLDSVL

B
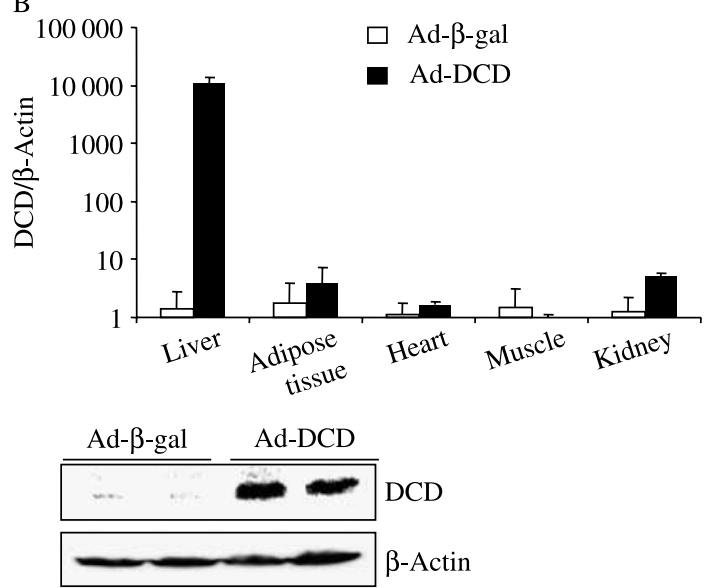

C
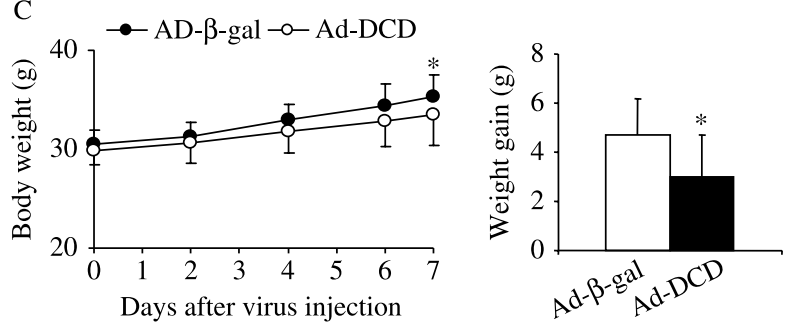

$\mathrm{D}$

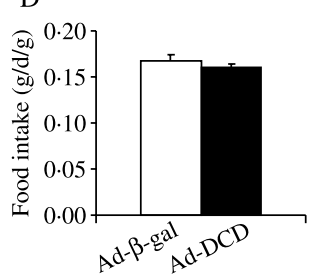

$\mathrm{E}$
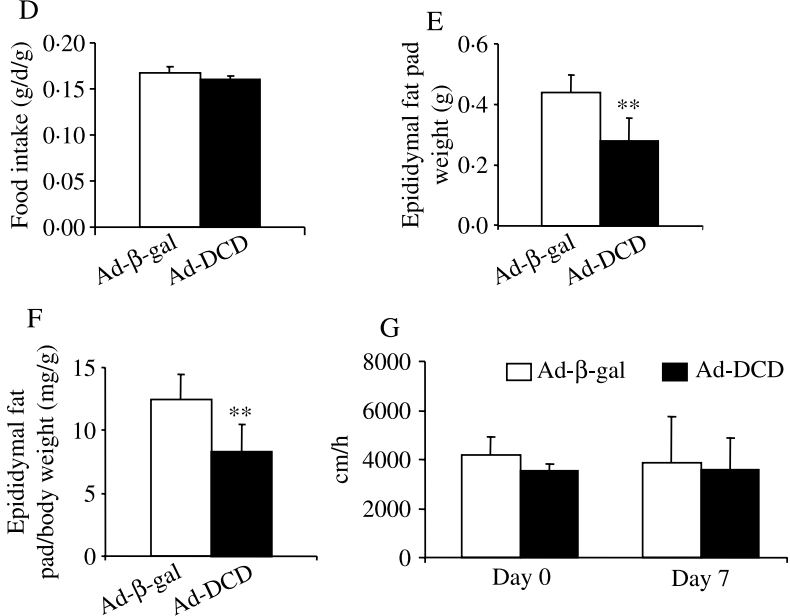

Figure 1 Phenotype characteristics of Ad-DCD- and Ad- $\beta$-galinjected animals. (A) Amino acid sequence of full-length DCD. The signal peptide (italics), PIF core peptide (bold), DSEP or Y-P 30 peptide (dotted underline), and DCD-1 (underline) are shown. (B) The expression levels of DCD in the liver were analyzed by RT-PCR and western blot analysis. (C) Body weight and weight gain, (D) food intake, (E) epididymal fat pad weight, and (F) the ratio of epididymal fat pad weight to body weight were measured in mice that received the Ad- $\beta$-gal or Ad-DCD virus ( $n=14-15$ mice/group). (G) Locomotor activity was measured in six mice of either Ad- $\beta$-gal- or Ad-DCD-injected animals. Values represent mean \pm s.E.M. $* P<0 \cdot 05, * * P<0 \cdot 01$ versus $A d-\beta$-gal-injected mice. been identified as a human cachectic factor, the exact enzymes required to generate the different products produced by the DCD gene, as well as the precise nature of the posttranslational modifications of human PIF, have not been fully elucidated. However, the different roles of the gene products of DCD suggest that DCD has antimicrobial and oncogenic functions, as well as a wide range of biological functions. Therefore, in this study, we investigated the effects of DCD in vivo when its systemic expression was increased in normal mice via adenovirus-mediated DCD gene transfer.

\section{Materials and Methods}

\section{Preparation of the recombinant adenovirus}

The E1/E3-deleted replication-deficient recombinant adenovirus was constructed using the AdEasy system (Quantum Biotechnologies, Montreal, Canada) following the method described by He et al. (1998). Briefly, the full-sequence fragment of DCD, including the secretion signal, was ligated into pShuttle cytomegalovirus (CMV). Recombination into the pAdEasy viral backbone was then accomplished in bacteria (Escherichia coli, strain BJ5183, which is recombination deficient) according to the manufacturer's instructions. Next, the recombination was verified, and the adenoviral recombinant DNA was then transferred to a regular E. coli strain $(\mathrm{DH} 5 \alpha)$, which generated greater yields of DNA. Recombinant pAdEasy plasmids containing CMV-cDNA inserts were then purified using Qiagen columns (Qiagen) and $5 \mu \mathrm{g}$ PacI-digested DNA was then used to transfect QBI293A cells by the calcium phosphate method (Promega). This process generated recombinant viruses that were termed Ad-DCD. A virus containing the bacterial $\beta$-galactosidase ( $\beta$-gal) gene under the control of the cytomegalovirus promoter (Ad- $\beta$-gal) was then prepared, purified, and titrated as described previously (Kim et al. 2007).

\section{Animals}

All experimental procedures were approved by the Institutional Animal Care and Use Committee at Chonbuk National University. Pathogen-free male ICR mice, purchased from the Korean Research Institute of Chemical Technology (Daejon, South Korea), housed in our animal facility and maintained with access to standard mouse food $(5 \%(\mathrm{w} / \mathrm{w})$ fat, $48 \%$ carbohydrate, and $18 \%$ protein) and water ad libitum. A total of $3 \times 10^{11}$ plaque-forming units of adenovirus were then administered intravenously to 5 -week-old mice weighing $\sim 20 \mathrm{~g}$ that had been anesthetized with xylazine and ketamine- $\mathrm{HCl}$. The food intake and body weight were then measured daily and every 2 days respectively for 7 days. All animals were killed under sodium pentobarbital anesthesia, after which their tissues were dissected immediately, weighed, and placed in half-strength Karnovsky's 
solution $(1 \cdot 6 \%$ paraformaldehyde and $1 \cdot 7 \%$ glutaraldehyde in $0 \cdot 1 \mathrm{M}$ PBS ( $\mathrm{pH} 7 \cdot 4)$ ) for adipocyte morphometry or frozen in liquid nitrogen for RNA extraction and western blot analysis.

\section{Cell culture}

Dr Orlicky (University of Colorado, Denver) provided 3T3L1CAR $\Delta 1$ cells (expressing the coxsackie-adenovirus receptor that improves adenoviral transduction efficiency; Orlicky et al. 2001). 3T3-L1CAR $\Delta 1$ preadipocytes were cultured in Dulbecco's modified Eagle's medium (DMEM) supplemented with $10 \%$ fetal bovine serum (FBS), $100 \mu \mathrm{g} / \mathrm{ml}$ streptomycin, and 100 units $/ \mathrm{ml}$ penicillin in humidified environment of $5 \% \mathrm{CO}_{2} / 95 \%$ air at $37^{\circ} \mathrm{C}$. Differentiation of confluent preadipocyte cultures was induced using DMEM containing $10 \%$ FBS, $1 \mu \mathrm{M}$ dexamethasone, $10 \mu \mathrm{g} / \mathrm{ml}$ insulin, and $0.5 \mathrm{mM}$ isobutylmethylxanthine. On day 2 , the medium was replaced with standard medium containing $5 \mu \mathrm{g} / \mathrm{ml}$ insulin and changed every other day for the following 4 days. To evaluate the direct effect of DCD on lipolysis, fully differentiated 3T3-L1CAR $\Delta 1$ cells were incubated with Ad- $\beta$-gal or Ad-DCD for $48 \mathrm{~h}$, and then TG hydrolysis was determined by measuring glycerol levels in culture media using Glycerol Reagent A (Zen-bio, Research Triangle Park, NC, USA).

\section{Locomotor activity}

Locomotor activity was determined by an automated activity monitoring system (Smart-CS, Penlab, Spain). Mice were acclimated for 3 days to the polycarbonate cages $(15 \mathrm{~cm} \times 20 \mathrm{~cm} \times 15 \mathrm{~cm})$ before locomotor behavior was quantified. At experimental day, mice were re-acclimated for $60 \mathrm{~min}$ and horizontal locomotor activity was quantified for $60 \mathrm{~min}$.

\section{Plasma measurements}

Plasma triglyceride (TG) was measured using a glycerol phosphate oxidase-Trinder TG kit (Sigma). Plasma free fatty acid (FFA) and glycerol were measured using a Wako NEFA kit (Wako, Osaka, Japan) and Glycerol Reagent A (Zen-bio) respectively. Plasma insulin was measured using an RIA kit (Linco Research, St Charles, MO, USA). Plasma tumor necrosis factor- $\alpha$ (TNF- $\alpha$ ) was assayed using the ELISA for TNF- $\alpha$ (R\&D Systems, Minneapolis, MN, USA).

\section{Adipocyte morphometry}

Epididymal adipose tissues were placed in half-strength Karnovsky's solution overnight, washed in $0 \cdot 1 \mathrm{M}$ PBS, and then cut into $\sim 4 \mathrm{~mm}$ blocks and dehydrated using graded acetone and embedded glycol methacrylate (EBSciences, East Granby, CT, USA). Once embedded, the sections (2 $\mu \mathrm{m}$ thick) were cut and stained with hematoxylin and eosin. To measure the adipocyte area, the sections were observed under an Axiophot microscope (Carl Zeiss, Oberkochen, Germany) and measured using analySIS 3.2 software (Soft-Imaging System, Muenster, Germany).

\section{RNA extraction, RT-PCR, and real-time PCR}

Total RNA was extracted from homogenized tissue using TRI reagent (Molecular Research Center, Cincinnati, OH, USA) according to the manufacturer's instructions. Reverse transcription (RT) was then performed in a mixture (final volume, $10 \mu \mathrm{l}$ ) that contained $2 \mu \mathrm{g}$ RNA and $2 \cdot 5 \mathrm{U}$ Avian myeloblastosis virus reverse transcriptase (Takara, Shiga, Japan) at $42{ }^{\circ} \mathrm{C}$ for $60 \mathrm{~min}$. Real-time PCR was performed using the LightCycler rapid thermal cycler system (Roche) according to the manufacturer's instructions, using specific primers for each gene (Table 1) that were designed using the LightCycler software 4 (Roche). Real-time PCR was conducted using a $20 \mu \mathrm{l}$ reaction mixture containing $100 \mathrm{ng}$ reverse transcribed total RNA, $500 \mathrm{nM}$ the forward and reverse primers, and $14 \mu \mathrm{l}$ of $2 \times \mathrm{SYBR}$ green buffer (Roche). The reaction consisted of a $10 \mathrm{~min}$ pre-incubation step at $95^{\circ} \mathrm{C}$, followed by 45 cycles of denaturation at $95^{\circ} \mathrm{C}$ for $10 \mathrm{~s}$, annealing at 58 (fatty acid synthase (FAS), hormone-sensitive

Table 1 Sequences and accession numbers for primers (forward, FOR, and reverse, REV) used in real-time RT-PCR

Sequences for primers

$\begin{array}{ll}\begin{array}{l}\text { Gene } \\ \beta \text {-actin }\end{array} & \\ \text { FOR: } & \text { 5'-GTGCTATGTTGCTCTAGACT-3' } \\ \text { REV: 5'-CACAGGATTCCATACCCAAG-3' } & \text { FOR: 5'-TGATGTGGAACACAGCAAGG-3' } \\ & \text { REV: 5'-GGCTGTGGTGACTCTTAGTGATAA-3' } \\ H S L & \text { FOR: 5'-GTTACCACCCTGCAGTCCTC-3' } \\ & \text { REV: 5'-AATGGTCCTCTGCCTCTGTC-3' } \\ \text { aFABP/aP2 } & \text { FOR: 5'-AGCCTTTCTCACCTGGAAGA-3' } \\ & \text { REV: 5'-TTGTGGCAAAGCCCACTC-3' } \\ T N F-\alpha & \text { FOR: 5'-TCTTCTCATTCCTGCTTGTGG-3' } \\ & \text { REV: 5'-GGTCTGGGCCATAGAACTGA-3' } \\ \text { Dermcidin } & \text { FOR: 5'-GTTAGCCAGACAGGCACCA-3' } \\ & \text { REV: 5'-CTCCGTCTAGGCCTTTTTCC-3' }\end{array}$

Accession no.

NM_007393.1

BC046513

BC021642

BC054426

NM_013693.1

NM_053283 
lipase (HSL), adipose fatty acid-binding protein (aFABP/ $\mathrm{aP2}$ ), and TNF- $\alpha$ ) or $63{ }^{\circ} \mathrm{C}$ ( $\beta$-actin) for $5 \mathrm{~s}$, and elongation at $72{ }^{\circ} \mathrm{C}$ for $10 \mathrm{~s}$. The relative concentrations of PCR product derived from the target gene were then calculated using the LightCycler System software. Results were expressed relative to the number of $\beta$-actin transcripts used as an internal control. All experiments were performed in triplicate.

\section{Western blot analysis}

The cells were homogenized in $100 \mu \mathrm{l}$ ice-cold lysis buffer (20 mM HEPES ( $\mathrm{pH} 7 \cdot 2$ ), 1\% Triton X-100, 10\% glycerol, $1 \mathrm{mM}$ phenylmethylsulfonyl fluoride, $10 \mu \mathrm{g} / \mathrm{ml}$ leupeptin, and $10 \mu \mathrm{g} / \mathrm{ml}$ aprotinin). Next, the homogenates, which contained $20 \mu \mathrm{g}$ protein, were separated by SDS-PAGE using a $10 \%$ acrylamide resolving and a 3\% stacking gel, and then transferred to nitrocellulose sheets in a western blot apparatus (Bio-Rad). The nitrocellulose paper was blocked with $2 \%$ BSA and then incubated for $4 \mathrm{~h}$ with $1 \mu \mathrm{g} / \mathrm{ml}$ primary antibody for perilipin (Sigma) or DCD (Santa Cruz Biotechnology, Santa Cruz, CA, USA). Horseradish peroxidase-conjugated IgG (Zymed, South San Francisco, CA, USA) was used as the secondary antibody. The protein expression levels were then determined by analyzing the signals captured on the nitrocellulose membranes using a Chemi-doc image analyzer (Bio-Rad).

\section{Immunohistochemistry for macrophage infiltration}

For immunohistochemical staining of epididymal adipose tissue to detect macrophages, the DAKO Envision system, which uses dextran polymers conjugated with horseradish peroxidase (DAKO, Carpinteria, CA, USA), was performed. The sections were incubated for $2 \mathrm{~h}$ at room temperature with anti-macrophage antibody (CD68, DAKO). The peroxidase activity was detected with the enzyme substrate 3-amino-9ethyl carbazole. For the negative controls, the sections were treated the same way except that they were incubated with Tris-buffered saline without the primary antibody.

\section{Statistical analysis}

All results are expressed as mean \pm S.E.M., and the difference between groups was calculated using Student's $t$-test. Differences with a $P<0.05$ were considered to be statistically significant.

\section{Results}

\section{Expression of DCD in liver after Ad-DCD virus injection}

In previous studies in which recombinant adenoviruses were administered to intact rodents, the reporter gene was primarily expressed in the liver (Herz \& Gerard 1993, Chen et al. 1996, Park et al. 2006). We used real-time PCR and western blot analysis to examine the expression of DCD in various tissues of normal 5-week-old mice that had been injected with either Ad- $\beta$-gal or Ad-DCD virus. Seven days after the virus was injected, DCD expression level was strongly increased in the liver of Ad-DCD-injected mice, whereas it was negligible in Ad- $\beta$-gal-injected mice indicating that the DCD gene is mainly expressed in the liver (Fig. 1B).

Effect of DCD on food intake, body weight, and epididymal fat pad weight

Adenovirus-mediated expression of DCD or $\beta$-gal in the liver had no effect on food intake 7 days after injection of the virus (Fig. 1D). However, the body weight gain in Ad-DCDinjected mice averaged $3.01 \pm 1.73 \mathrm{~g}$ per 7 days, whereas it averaged $4 \cdot 71 \pm 1 \cdot 48 \mathrm{~g}$ in Ad- $\beta$-gal-injected mice (Fig. 1C). Furthermore, the epididymal adipose weight, as well as the ratio of epididymal fat pad weight to body weight, was lower in Ad-DCD-injected animals (Fig. 1E and F), indicating that body weight and body fat are significantly decreased in normal mice that received the DCD virus. When locomotor activity was measured to investigate whether changes in physical activity could account for the lower body weight and adiposity observed in Ad-DCD-injected mice, there was no difference between Ad- $\beta$-gal-injected and Ad-DCD-injected mice (Fig. 1G).

\section{Effect of DCD on plasma TG, FFA, and glycerol levels}

The circulating TG concentrations were lower in Ad-DCDinjected mice than in Ad- $\beta$-gal-injected mice 7 days after injection of the virus (Fig. 2A). However, significant increases in the FFA and glycerol levels were observed in Ad-DCDinjected mice (Fig. 2B and $\mathrm{C}$ ), suggesting that the increase of FFA and glycerol flux is resulted from the increased lipolysis in adipose tissue. Plasma insulin levels of Ad- $\beta$-galand Ad-DCD-injected mice averaged $0.58 \pm 0.21$ and $0 \cdot 41 \pm 0 \cdot 21 \mathrm{ng} / \mathrm{ml}(P=0 \cdot 104, n=12)$ respectively, indicating that DCD has no effect on plasma insulin levels.

\section{Effect of DCD on fat cell size}

The size of the fat cells in the epididymal fat is displayed in Fig. 3. The epididymal fat cells were smaller in Ad-DCDinjected mice than in Ad- $\beta$-gal-injected mice 7 days after the virus was injected.

Effects of DCD on the expression of genes involved in lipid metabolism in adipose tissue

To determine whether the effect of DCD on body fat reduction is related to the modified expressions of proteins that regulate lipid metabolism, we isolated epididymal fat from Ad-DCD- or Ad- $\beta$-gal-injected mice, and then measured the mRNA levels. Adenovirus-mediated expression of DCD had no effect on the expression of $F A S$ 
A
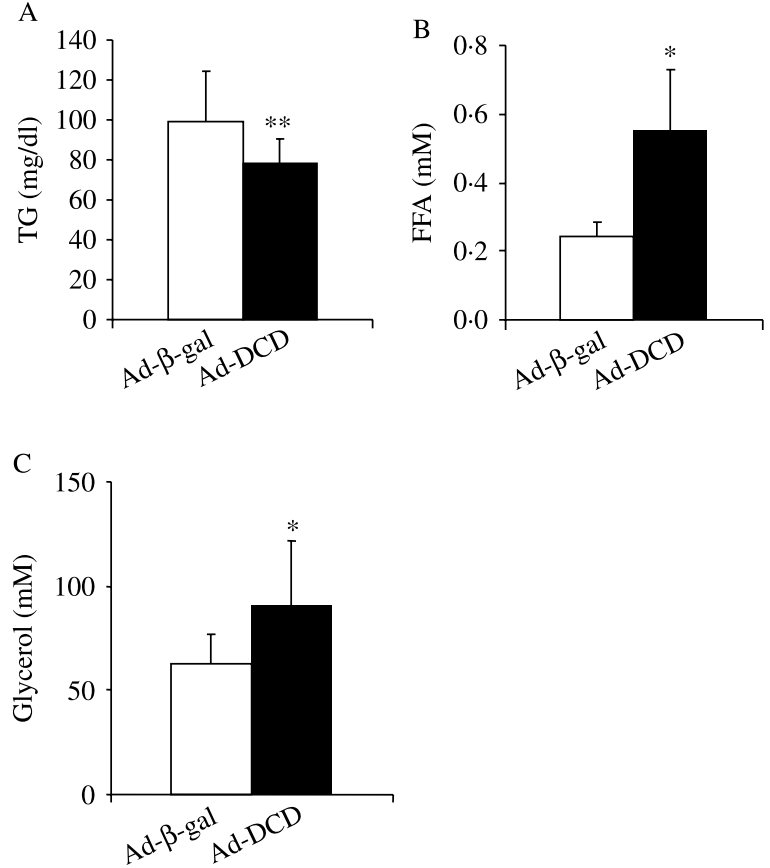

Figure 2 Plasma TG, FFA, and glycerol levels in Ad- $\beta$-galand Ad-DCD-injected mice. (A) Plasma TG, (B) FFA, and (C) glycerol levels were measured 7 days after the injection of the virus ( $n=14-15 \mathrm{mice} /$ group). Values represent mean \pm S.E.M.

${ }^{*} P<0 \cdot 05,{ }^{*} P<0 \cdot 01$ versus Ad- $\beta$-gal-injected mice.

mRNA. However, mRNA levels of $H S L$ and $a F A B P / a P 2$ were increased in mice that were injected with $\mathrm{DCD}$ virus (Fig. 4A). These observations suggest that DCD is involved in the activation of lipolysis through the increased levels of lipolytic gene expression in adipose tissue.

\section{Effects of DCD on TNF- $\alpha$ and perilipin levels}

The adenovirus-mediated DCD overexpression in the liver was shown to induce lipolysis in adipose tissue; therefore, we conducted experiments to determine whether a direct effect of DCD on lipolysis could be observed in vitro. When differentiated adipocytes obtained from 3T3-L1 preadipocyte were infected with Ad-DCD virus, no change in glycerol release as a result of TG hydrolysis was observed, although the mRNA level of DCD in the differentiated adipocytes was increased 3 days after infection (data not shown). Concentration-dependent stimulation of lipolysis by TNF- $\alpha$ has been demonstrated in rodent and human fat cells (Green et al. 1994, Ryden et al. 2002); therefore, we next evaluated the TNF- $\alpha$ levels in plasma as well as TNF- $\alpha$ mRNA levels in adipose tissue to further investigate the molecular mechanism by which DCD increased lipolysis. As shown in Fig. 4A and B, both the mRNA levels of TNF- $\alpha$ in adipose tissue and the circulating TNF- $\alpha$ levels in plasma were increased in Ad-DCD-injected mice. It is not clear how TNF- $\alpha$ activates lipolysis; however, recent studies conducted on 3T3-L1 cells
A
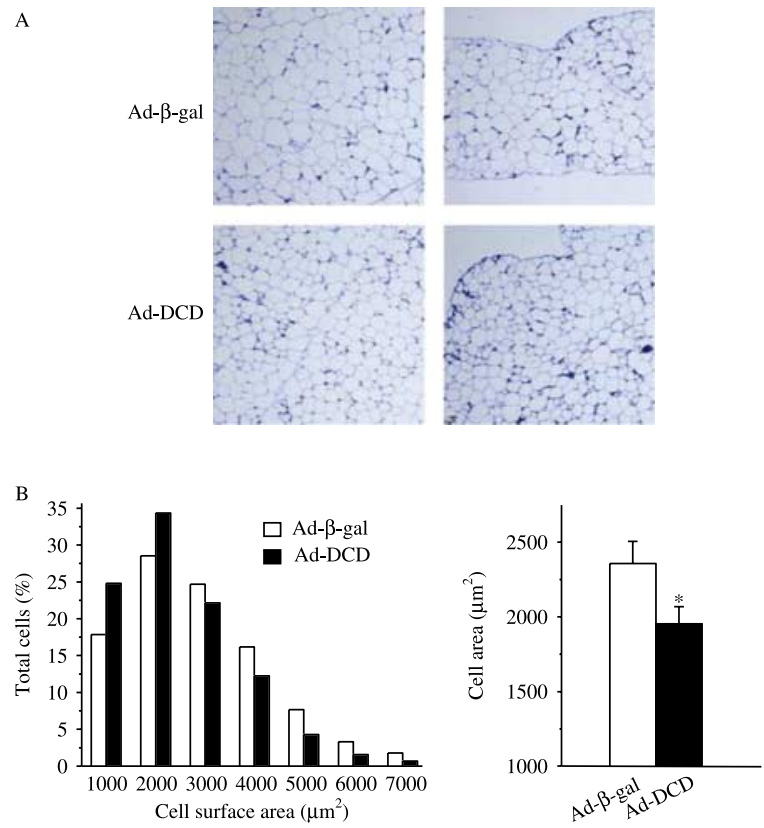

Figure 3 Effect of DCD on fat cell size. (A) Sections of epididymal adipose tissue obtained from Ad- $\beta$-gal- or Ad-DCD-injected mice were H\&E stained. (B) The average size of the fat cells was then calculated as described in 'Materials and Methods'. Values represent mean \pm s.E.M. ${ }^{*} P<0 \cdot 05$ versus $A d$ - $\beta$-gal-injected mice.

have shown that TNF- $\alpha$ downregulates the expression of the lipid droplet-associated protein, perilipin, which is thought to modulate the accession of HSL to the surface of the fat droplet (Souza et al. 1998, 2003). As shown in Fig. 4C, protein levels of perilipin in adipose tissue were lower in Ad-DCD-injected mice than in control mice, suggesting that DCD-mediated body fat reduction might occur as a result of TNF- $\alpha$-induced lipolysis by perilipin downregulation in adipose tissue. Since TNF- $\alpha$ is mainly produced by macrophage (Ryden \& Arner 2007), we asked whether Ad-DCD injection could affect macrophage infiltration into adipose tissue. The degree of macrophage infiltration in epididymal fat was determined by examining the immunohistochemistry of anti-CD68 staining under microscopy. Immunohistochemistry of Ad-DCD-injected mice showed that numerous CD68 positive macrophages were found in perivascular area of epididymal fat (Fig. 5A). However, it was hard to observe macrophages in epididymal adipose tissue of Ad- $\beta$-galinjected mice (Fig. 5B).

\section{Discussion}

DCD contains the PIF core peptide; therefore, it is considered to be a human homolog of mouse PIF, which is identified as a cachectic factor that was purified in cachexia-inducing murine tumors and urine of weight-losing patients with cancer (Todorov et al. 1996, Wigmore et al. 2000, Monitto 

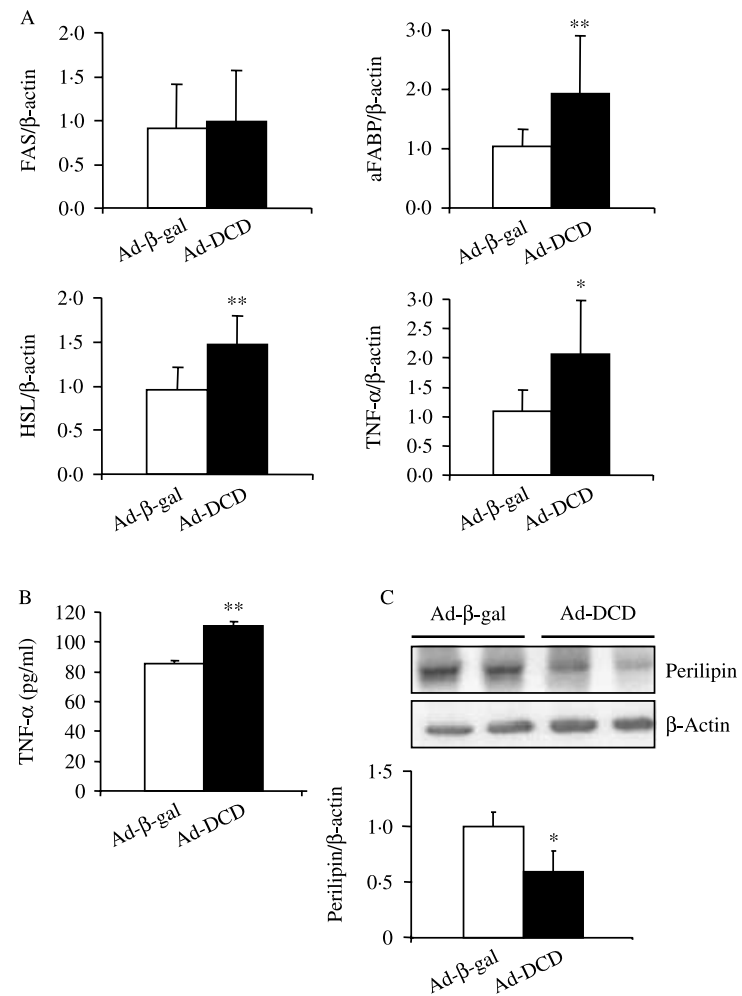

Figure 4 Effect of DCD on the levels of factors involved in lipolysis. (A) mRNA levels of $H S L, a F A B P / a P 2, F A S$, and $T N F-\alpha$ were measured by real-time PCR ( $n=13$ mice/group) in adipose tissue obtained from Ad- $\beta$-gal- or Ad-DCD-injected mice. (B) Circulating TNF- $\alpha$ was measured in plasma samples by ELISA. (C) Protein levels of perilipin in adipose tissue were analyzed by western blotting. Values represent mean \pm s.E.M. ${ }^{*} P<0 \cdot 05,{ }^{*} P<0 \cdot 01$ versus $A d-\beta$ gal-injected mice.

et al. 2004). One of the most devastating effects of cachexia is a progressive loss of body weight, which results in severe depletion of both adipose tissue and skeletal muscle (Tisdale 2005). Weight-losing cancer patients show an increased turnover of fatty acids when compared with cancer patients without weight loss (Legaspi et al. 1987, Shaw \& Wolfe 1987). In this study, we observed that body weight gain, as well as epididymal fat weight, was significantly decreased in
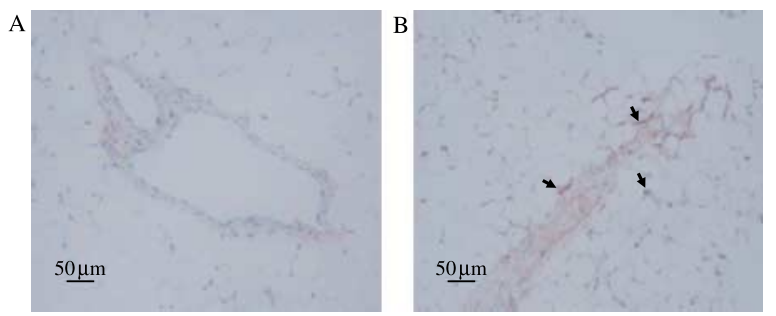

Figure 5 Macrophage infiltration in epididymal adipose tissue. Epididymal adipose tissue from (A) an Ad- $\beta$-gal- or (B) Ad-DCDinjected mice was stained with an antibody against CD68, a macrophage-specific cell surface antigen. Arrows indicate infiltrated CD68 positive macrophage.
Ad-DCD-injected mice without any change in food intake or physical activity. We also found the smaller epididymal fat cell size and the higher plasma FFA and glycerol in Ad-DCDinjected mice, suggesting increased lipolysis in adipose tissue.

Catecholamines bind to $\beta$-adrenergic receptors on adipocytes, resulting in upregulation of adenylate cyclase, activation of cAMP-dependent protein kinase (PKA), and activation of HSL (Belfrage et al. 1982). In addition to the activation of HSL, PKA also modulates the action of lipid droplet-associated phosphoprotein, perilipin (Tansey et al. 2004, Miyoshi et al. 2007). Perilipin A is the most prevalent PKA substrate found in adipocytes. In the basal state, perilipin acts as a barrier to lipases, thereby maintaining a low rate of basal lipolysis. However, upon phosphorylation by PKA, perilipin facilitates the accessibility of lipases to lipid stores, thereby promoting lipolysis (Brasaemle et al. 2000, Martinez-Botas et al. 2000, Tansey et al. 2001, Souza et al. 2002, Zhang et al. 2003, Marcinkiewicz et al. 2006). In the current study, the mRNA level of HSL was increased, whereas the protein level of perilipin was decreased in Ad-DCD-injected mice. Therefore, it is likely that DCD induced the activation of lipolysis by increasing the expression of lipolytic enzyme (HSL) and by decreasing the expression of the lipase barrier (perilipin), both of which can promote TG hydrolysis, and consequently decrease body fat mass. Additionally, the mRNA level of $F A B P$ was increased in the adipose tissue of Ad-DCD-injected mice. Cytosolic FABPs form complex with HSL and provide solubility and intracellular trafficking of long-chain fatty acids (Coe et al. 1999, Zimmerman \& Veerkamp 2002). Actually, a knockout of adipocyte FABP (aFABP/aP2) was shown to decrease the in vivo lipolysis rate (Scheja et al. 1999, Baar et al. 2005). Therefore, the Ad-DCD-induced increase in the aFABP/aP2 mRNA level appeared to be involved in the increased lipolysis of adipose tissue in DCD virus-injected mice.

TNF- $\alpha$ plays an important role among the factors believed to be involved in the development of cancer cachexia. TNF- $\alpha$ has been identified as a polypeptide responsible for cachexia (hence the alternative name is cachectin; Beutler et al. 1985). Circulating TNF- $\alpha$ levels are elevated in plasma obtained from patients with cachectic states caused by parasitic infections, bacterial septicemia, and several forms of cancer (Ryden \& Arner 2007). Furthermore, in vitro studies in both rodents and humans have demonstrated that TNF- $\alpha$ stimulates adipocyte lipolysis (Green et al. 1994, Ryden et al. 2002). In adipocyte cell culture, TNF- $\alpha$ stimulation of lipolysis is only observed after $6-12 \mathrm{~h}$ and is therefore dependent on altered gene transcription and/or protein expression (Gasic, et al. 1999). TNF- $\alpha$ activation has been shown to lead to downregulation of perilipin (Ryden et al. 2002, 2004, Zhang et al. 2002). This effect is dependent upon the stimulation of the mitogen-activated protein kinases, $\mathrm{p} 44$ / 42 , and the $\mathrm{NH}_{2}$-terminal jun kinase (Zhang et al. 2002, Ryden et al. 2004). The present study demonstrated that injection with the Ad-DCD virus induced an increase in the concentration of the circulating TNF- $\alpha$. In addition, 
the finding that a lower expression level of perilipin protein occurred in Ad-DCD-injected mice suggests that TNF- $\alpha$ may be one of the important candidates involved in the DCD-mediated increase of lipolysis through decreasing perilipin expression.

In the present study, Ad-DCD injection into mice caused an increase in the TNF- $\alpha$ mRNA level in adipose tissue. However, in differentiated 3T3-L1 adipocytes infected with the Ad-DCD virus, we could not find any changes in the amount of glycerol released from TG droplets, even though the mRNA level of $D C D$ in differentiated adipocytes was significantly increased 3 days after infection (data not shown). In addition, we could not find any changes in mRNA level of $T N F-\alpha$ in differentiated adipocytes and concentration of TNF- $\alpha$ in culture media (data not shown). This discrepancy between the in vivo and in vitro results may be due to the source of TNF- $\alpha$. Adipose tissue contains a variety of inflammatory cells in addition to adipocytes. Infiltrating macrophage is known as the major source of TNF- $\alpha$ production in adipose tissue. Indeed, immunohistochemistry of anti-CD68 staining showed that CD68 positive macrophages were found in perivascular area of epididymal fat from Ad-DCD-injected mice. These data suggest that the effect of DCD on lipolysis is through its action for increasing macrophage infiltration and TNF- $\alpha$ levels in adipose tissue. The macrophage infiltration has been reported in adipose tissue of obese patients and overproduction of TNF- $\alpha$ by adipose tissue from obese animal models has been considered to play a major role in the pathophysiology of insulin resistance (Hotamisligil et al. 1993, Weisberg et al. 2003, Cancello et al. 2005, Cinti et al. 2005). Therefore, the possible role of DCD in the development of insulin resistance requires further investigation.

DCD protein was composed of several different peptides, including the PIF core peptide and DCD-1. Although it is not clear how these polypeptides are produced from the entire DCD protein, it is likely that differential proteolysis is responsible for the production of the different DCD peptides. Four different peptides have been identified in sweat, and all of these peptides appear to be proteolytic products (Flad et al. 2002). However, the specific proteases involved in differential proteolysis remain to be determined. In the present study, we demonstrated that, in addition to its functions as an antimicrobial peptide and a survival factor in cancer cells, DCD has a potential effect on adipocyte lipolysis. However, because we used the full sequence of DCD in this study, the precise domain of DCD that is responsible for its role in adipocyte lipolysis remains to be determined.

In summary, we have shown that, in vivo, an adenovirusmediated increase in DCD expression induced adipose tissue lipolysis, and this occurred partly through TNF- $\alpha$-dependent mechanisms. The increased lipolysis in DCD-injected animals may be responsible for the decreased body fat mass. Although the factors underlying the loss of muscle mass that occurs in cachexia have been intensively investigated, little is known about the factors that cause the loss of fat mass that precedes muscle wasting. The results of this study indicate that DCD may serve as a factor in the mobilization of body fat, and that DCD contributes to the substantial reduction of adipose tissue that occurs in cases of cancer cachexia.

\section{Declaration of Interest}

The authors declare that there is no conflict of interest that would prejudice the impartiality of this scientific work.

\section{Funding}

This work was supported by the Korea Research Foundation Grant (KRF-2005-042-E00005).

\section{References}

Baar RA, Dingfelder CS, Smith LA, Bernlohr DA, Wu C, Lange AJ \& Parks EJ 2005 Investigation of in vivo fatty acid metabolism in AFABP/aP2 $(-/-)$ mice. American Journal of Physiology. Endocrinology and Metabolism 288 E187-E193.

Belfrage P, Fredrikson G, Olsson H \& Stralfors P 1982 Hormonal regulation of adipose tissue lipolysis by reversible phosphorylation of hormonesensitive lipase. Progress in Clinical and Biological Research 102 213-223.

Beutler B, Greenwald D, Hulmes JD, Chang M, Pan YC, Mathison J, Ulevitch R \& Cerami A 1985 Identity of tumour necrosis factor and the macrophage-secreted factor cachectin. Nature 316 552-554.

Brasaemle DL, Rubin B, Harten IA, Gruia-Gray J, Kimmel AR \& Londos C 2000 Perilipin A increases triacylglycerol storage by decreasing the rate of triacylglycerol hydrolysis. Journal of Biological Chemistry 275 38486-38493.

Cancello R, Henegar C, Viguerie N, Taleb S, Poitou C, Rouault C, Coupaye M, Pelloux V, Hugol D, Bouillot JL et al. 2005 Reduction of macrophage infiltration and chemoattractant gene expression changes in white adipose tissue of morbidly obese subjects after surgery-induced weight loss. Diabetes 54 2277-2286.

Chen G, Koyama K, Yuan X, Lee Y, Zhou YT, O'Doherty R, Newgard CB \& Unger RH 1996 Disappearance of body fat in normal rats induced by adenovirus-mediated leptin gene therapy. PNAS 93 14795-14799.

Cinti S, Mitchell G, Barbatelli G, Murano I, Ceresi E, Faloia E, Wang S, Fortier M, Greenberg AS \& Obin MS 2005 Adipocyte death defines macrophage localization and function in adipose tissue of obese mice and humans. Journal of Lipid Research 46 2347-2355.

Coe NR, Simpson MA \& Bernlohr DA 1999 Targeted disruption of the adipocyte lipid-binding protein (aP2 protein) gene impairs fat cell lipolysis and increases cellular fatty acid levels. Journal of Lipid Research 40 967-972.

Cunningham TJ, Hodge L, Speicher D, Reim D, Tyler-Polsz C, Levitt P, Eagleson K, Kennedy S \& Wang Y 1998 Identification of a survivalpromoting peptide in medium conditioned by oxidatively stressed cell lines of nervous system origin. Journal of Neuroscience 18 7047-7060.

Cunningham TJ, Jing H, Akerblom I, Morgan R, Fisher TS \& Neveu M 2002 Identification of the human cDNA for new survival/evasion peptide (DSEP): studies in vitro and in vivo of overexpression by neural cells. Experimental Neurology 177 32-39.

Flad T, Bogumil R, Tolson J, Schittek B, Garbe C, Deeg M, Mueller CA \& Kalbacher H 2002 Detection of dermcidin-derived peptides in sweat by ProteinChip technology. Journal of Immunological Methods 270 53-62.

Gasic S, Tian B \& Green A 1999 Tumor necrosis factor $\boldsymbol{\alpha}$ stimulates lipolysis in adipocytes by decreasing Gi protein concentrations. Journal of Biological Chemistry 274 6770-6775.

Green A, Dobias SB, Walters DJ \& Brasier AR 1994 Tumor necrosis factor increases the rate of lipolysis in primary cultures of adipocytes without altering levels of hormone-sensitive lipase. Endocrinology 134 2581-2588. 
He TC, Zhou S, da Costa LT, Yu J, Kinzler KW \& Vogelstein B 1998 A simplified system for generating recombinant adenoviruses. PNAS 95 2509-2514.

Herz J \& Gerard RD 1993 Adenovirus-mediated transfer of low density lipoprotein receptor gene acutely accelerates cholesterol clearance in normal mice. PNAS 90 2812-2816.

Hotamisligil GS, Shargill NS \& Spiegelman BM 1993 Adipose expression of tumor necrosis factor- $\alpha$ : direct role in obesity-linked insulin resistance. Science 259 87-91.

Kim EK, Kwon KB, Koo BS, Han MJ, Song MY, Song EK, Han MK, Park JW, Ryu DG \& Park BH 2007 Activation of peroxisome proliferatoractivated receptor- $\gamma$ protects pancreatic $\beta$-cells from cytokine-induced cytotoxicity via NFKB pathway. International Journal of Biochemistry and Cell Biology 39 1260-1275.

Lai YP, Peng YF, Zuo Y, Li J, Huang J, Wang LF \& Wu ZR 2005 Functional and structural characterization of recombinant dermcidin-1L, a human antimicrobial peptide. Biochemical and Biophysical Research Communications 328 243-250.

Legaspi A, Jeevanandam M, Starnes HF Jr \& Brennan MF 1987 Whole body lipid and energy metabolism in the cancer patient. Metabolism 36 958-963.

Lorite MJ, Cariuk P \& Tisdale MJ 1997 Induction of muscle protein degradation by a tumour factor. British Journal of Cancer 76 1035-1040.

Lorite MJ, Thompson MG, Drake JL, Carling G \& Tisdale MJ 1998 Mechanism of muscle protein degradation induced by a cancer cachectic factor. British Journal of Cancer 78 850-856.

Lowrie AG, Wigmore SJ, Wright DJ, Waddell ID \& Ross JA 2006 Dermcidin expression in hepatic cells improves survival without $N$-glycosylation, but requires asparagine residues. British Journal of Cancer 94 1663-1671.

Marcinkiewicz A, Gauthier D, Garcia A \& Brasaemle DL 2006 The phosphorylation of serine 492 of perilipin a directs lipid droplet fragmentation and dispersion. Journal of Biological Chemistry 281 11901-11909.

Martinez-Botas J, Anderson JB, Tessier D, Lapillonne A, Chang BH, Quast MJ, Gorenstein D, Chen KH \& Chan L 2000 Absence of perilipin results in leanness and reverses obesity in Lepr $(\mathrm{db} / \mathrm{db})$ mice. Nature Genetics 26 474-479.

Miyoshi H, Perfield JW II, Souza SC, Shen WJ, Zhang HH, Stancheva ZS, Kraemer FB, Obin MS \& Greenberg AS 2007 Control of adipose triglyceride lipase action by serine 517 of perilipin A globally regulates protein kinase A-stimulated lipolysis in adipocytes. Journal of Biological Chemistry 282 996-1002.

Monitto CL, Dong SM, Jen J \& Sidransky D 2004 Characterization of a human homologue of proteolysis-inducing factor and its role in cancer cachexia. Clinical Cancer Research 10 5862-5869.

Orlicky DJ, DeGregori J \& Schaack J 2001 Construction of stable coxsackievirus and adenovirus receptor-expressing 3T3-L1 cells. Journal of Lipid Research 42 910-915.

Park BH, Wang MY, Lee Y, Yu X, Ravazzola M, Orci L \& Unger RH 2006 Combined leptin actions on adipose tissue and hypothalamus are required to deplete adipocyte fat in lean rats: implications for obesity treatment. Journal of Biological Chemistry 281 40283-40291.

Porter D, Weremowicz S, Chin K, Seth P, Keshaviah A, Lahti-Domenici J, Bae YK, Monitto CL, Merlos-Suarez A, Chan J et al. 2003 A neural survival factor is a candidate oncogene in breast cancer. PNAS 100 10931-10936.

Ryden M \& Arner P 2007 Tumour necrosis factor- $\alpha$ in human adipose tissue - from signalling mechanisms to clinical implications. Journal of Internal Medicine 262 431-438.

Ryden M, Dicker A, van Harmelen V, Hauner H, Brunnberg M, Perbeck L, Lonnqvist F \& Arner P 2002 Mapping of early signaling events in tumor necrosis factor- $\boldsymbol{\alpha}$-mediated lipolysis in human fat cells. Journal of Biological Chemistry 277 1085-1091.

Ryden M, Arvidsson E, Blomqvist L, Perbeck L, Dicker A \& Arner P 2004 Targets for TNF- $\alpha$-induced lipolysis in human adipocytes. Biochemical and Biophysical Research Communications 318 168-175.

Scheja L, Makowski L, Uysal KT, Wiesbrock SM, Shimshek DR, Meyers DS, Morgan M, Parker RA \& Hotamisligil GS 1999 Altered insulin secretion associated with reduced lipolytic efficiency in aP2 $-/-$ mice. Diabetes 48 1987-1994.
Schittek B, Hipfel R, Sauer B, Bauer J, Kalbacher H, Stevanovic S, Schirle M, Schroeder K, Blin N, Meier F et al. 2001 Dermcidin: a novel human antibiotic peptide secreted by sweat glands. Nature Immunology 2 1133-1137.

Shaw JH \& Wolfe RR 1987 Fatty acid and glycerol kinetics in septic patients and in patients with gastrointestinal cancer. The response to glucose infusion and parenteral feeding. Annals of Surgery 205 368-376.

Smith HJ, Lorite MJ \& Tisdale MJ 1999 Effect of a cancer cachectic factor on protein synthesis/degradation in murine C2C12 myoblasts: modulation by eicosapentaenoic acid. Cancer Research 59 5507-5513.

Souza SC, de Vargas LM, Yamamoto MT, Lien P, Franciosa MD, Moss LG \& Greenberg AS 1998 Overexpression of perilipin A and B blocks the ability of tumor necrosis factor $\alpha$ to increase lipolysis in 3T3-L1 adipocytes. Journal of Biological Chemistry 273 24665-24669.

Souza SC, Muliro KV, Liscum L, Lien P, Yamamoto MT, Schaffer JE, Dallal GE, Wang X, Kraemer FB, Obin M et al. 2002 Modulation of hormonesensitive lipase and protein kinase A-mediated lipolysis by perilipin A in an adenoviral reconstituted system. Journal of Biological Chemistry 277 8267-8272.

Souza SC, Palmer HJ, Kang YH, Yamamoto MT, Muliro KV, Paulson KE \& Greenberg AS 2003 TNF- $\alpha$ induction of lipolysis is mediated through activation of the extracellular signal related kinase pathway in 3T3-L1 adipocytes. Journal of Cellular Biochemistry 89 1077-1086.

Stewart GD, Lowrie AG, Riddick AC, Fearon KC, Habib FK \& Ross JA 2007 Dermcidin expression confers a survival advantage in prostate cancer cells subjected to oxidative stress or hypoxia. Prostate 67 1308-1317.

Tansey JT, Sztalryd C, Gruia-Gray J, Roush DL, Zee JV, Gavrilova O, Reitman ML, Deng CX, Li C, Kimmel AR et al. 2001 Perilipin ablation results in a lean mouse with aberrant adipocyte lipolysis, enhanced leptin production, and resistance to diet-induced obesity. PNAS 98 6494-6499.

Tansey JT, Sztalryd C, Hlavin EM, Kimmel AR \& Londos C 2004 The central role of perilipin a in lipid metabolism and adipocyte lipolysis. IUBMB Life 56 379-385.

Tisdale MJ 2005 Molecular pathways leading to cancer cachexia. Physiology 20 340-348.

Todorov P, Cariuk P, McDevitt T, Coles B, Fearon K \& Tisdale M 1996 Characterization of a cancer cachectic factor. Nature 379 739-742.

Vuong C, Voyich JM, Fischer ER, Braughton KR, Whitney AR, DeLeo FR \& Otto M 2004 Polysaccharide intercellular adhesin (PIA) protects Staphylococcus epidermidis against major components of the human innate immune system. Cellular Microbiology 6 269-275.

Weisberg SP, McCann D, Desai M, Rosenbaum M, Leibel RL \& Ferrante AW Jr 2003 Obesity is associated with macrophage accumulation in adipose tissue. Journal of Clinical Investigation 112 1796-1808.

Wigmore SJ, Todorov PT, Barber MD, Ross JA, Tisdale MJ \& Fearon KC 2000 Characteristics of patients with pancreatic cancer expressing a novel cancer cachectic factor. British Journal of Surgery 87 53-58.

Zhang HH, Halbleib M, Ahmad F, Manganiello VC \& Greenberg AS 2002 Tumor necrosis factor- $\alpha$ stimulates lipolysis in differentiated human adipocytes through activation of extracellular signal-related kinase and elevation of intracellular cAMP. Diabetes 51 2929-2935.

Zhang HH, Souza SC, Muliro KV, Kraemer FB, Obin MS \& Greenberg AS 2003 Lipase-selective functional domains of perilipin A differentially regulate constitutive and protein kinase A-stimulated lipolysis. Journal of Biological Chemistry 278 51535-51542.

Zimmerman AW \& Veerkamp JH 2002 New insights into the structure and function of fatty acid-binding proteins. Cellular and Molecular Life Sciences $\mathbf{5 9}$ 1096-1116.

\section{Received in final form 10 April 2008 \\ Accepted 8 May 2008 \\ Made available online as an Accepted Preprint 8 May 2008}

